\title{
Sinyalizasyonlu Kavşak Yaklaşımında Üstyapı Düzgünsüzlüğü ile Sürücü Davranışı Etkileşiminin Değerlendirilmesi
}

\author{
${ }^{1}$ Ayşe Ünal, ${ }^{1}$ Meltem Saplıŏlu, ${ }^{1}$ Melek Böcek \\ ${ }^{1}$ Süleyman Demirel Üniversitesi, Mühendislik Fakültesi, İnşaat Müh. Bölümü, Isparta, Türkiye
}

\section{ÖZET}

Yol üst yapısında ki düzgünsüzlüğün sürüş konforunu önemli ölçüde etkilediği bilinmektedir. Son yıllarda yapılan çalışmalarda bu olumsuz etkinin yol güvenliği üzerinde de payı olduğu yönündedir. Literatürde üstyapı düzgünsüzlüğü (IRI) ile ilgili birçok çalışma mevcut olmasına rağmen şehiriçi kavşak yaklaşımında sürücü hız davranışı ile ilişkisine rastlamak zordur. Bu çalışma kapsamında; kent içi yol güvenliği açısından kritik noktalar olan kavşaklarda, üstyapı düzgünsüzlük (IRI) etkisinin sürücü davranışı ile ilişkisi değerlendirilmeye çalışılmıştır. Değerlendirmeler sonucunda, kavşak merkezine doğru IRI değeri artıkça hız değerlerinin azaldığı tespit edilmiştir. İleriki çalışmalarda uygulamanın farklı tip ve daha fazla kavşakta yapılması ile daha detaylı sonuçlara ulaşılabileceği düşünülmektedir.

Anahtar Kelimeler: Düzgünsüzlük (IRI), Sürücü Davranışı, Hız, Monte Carlo Yöntemi.

\begin{abstract}
It is known that roughness on flexible pavement, significantly affects driving comfort. In recent years, studies have shown that this negative effect also contributes negatively to road safety. Although there are many studies on superstructure roughness (IRI) in literature, it is difficult to find any studies ITS relationship with driver speed behavior in urban interchange approach. In the scope of this work, it has been tried to evaluate the effect of pavement roughness on driver behavior at intersections which are critical locations in terms of road safety in cities. According to the results, while the IRI value increased towards the intersection center, the values of the speeds decreased. It is thought that more detailed results can be obtained by carrying out the application in more intersections with different lay outs for the next studies.
\end{abstract}

Key Words: Roughness, Driver Behavior, Speed, Monte Carlo Method.

\section{GíRiş}

Karayolu üstyapıları proje ömürleri boyunca, trafik yüklerinden ve iklim değişikliğinden kaynaklı gerilmelere maruz kalmaktadır. Tüm bu gerilmeler yol üstyapısında bozulmalara sebep olmaktadır. Bozulmalar (çatlaklar, kalıcı deformasyonlar, suya bağlı bozulmalar vb.) karayolunun servis kabiliyetini olumsuz yönde etkilemektedir. Düzgünsüzlük ise yol üst yapısında meydana gelen bozulmalardan kaynaklı, daha uzun kesit mesafelerinde hissedilen, konforsuz sürüşe neden olan bir üstyapı sorunudur. Yapılan çalışmalarda, düşey doğrultuda meydana gelen titreşimler sürücü ve yolcu konfor değerlendirmelerinde önemli bir faktör olarak görülmektedir [1,2]. Sürüş sırasında araç içinde hem araç kullanıcısı hem de yolcu açısından düşey eksen doğrultusundaki titreşimlerin oluşmasında iki ana sebep gösterilebilir. Bunlar, taşıtın mekanik yapısı ve üstyapıda görülen bozulmalar ve düzgünsüzlüktür $[1,2]$. Düzgünsüzlük, rahatsız edici bir sürüşe neden olan, üstyapı yüzeyinden kaynaklanan olumsuz bir durumdur.

Düzgünsüzlüğü yüksek olan bir üstyapı yüzeyinden geçen araçtaki yolcular, dikey bir sarsıntıya maruz kalmaktadırlar. Düzgünsüzlüğün araç fonksiyonlarını etkileme derecesi; üstyap1 
bozukluğunun boyutları, sıklığı, taşıtın süspansiyon özellikleri ve araç hızı gibi faktörlere bağlıdır. Üstyapı düzgünlüğü önemlidir, çünkü düzgünsüzlük servis kabiliyeti ve maliyetler ile doğrudan ilişkilidir [3]. Ayrıca düzgünsüzlüğün araştırılıp nedenlerinin bilinmesi üstyapı yönetim sisteminin (ÜYS) verimli işletilmesinde ve üstyapı tasarım analizlerinin doğru yapılmasında oldukça faydalı bilgiler sağlamaktadır $[4,5]$.

Çalışmalarda üstyapının mevcut durumunu belirlemede çoğunlukla Uluslararası Düzgünsüzlük İndeksinin (International Roughness Index, IRI) kullanıldığı, düzgünsüzlüğün sürüş konforuna ve güvenliğine etkisinin çoğunlukla bu parametre ile belirlendiği görülmektedir. Dünya Bankası tarafından ASTM E 950 koduyla geliştirilen standartta IRI'nın Hizmet Düzeyi (Present Serviceability Index, PSI) ile doğrudan ilişkili olduğu belirtilmektedir [4, 24]. İlk aşamada düzgünsüzlükle ilişkili olarak, yolların performans seviyelerini değerlendirebilmek için üstyap1 servis yeteneği indeksi (PSI), Sürüş konforu indeksi (RCI), sürüş sayısı (RN) gibi çeşitli değerlendirme ölçütleri geliştirilmiştir [6]. Fakat kullanılan yöntemlerin farklı olmasından ve bölgesel değişikliklerden dolayı kaynaklar bir araya getirilememiş, değerlendirme kriterleri net olarak ortaya konamamış, evrensel bir standart oluşturulamamıştır. Bu noktada; Dünya Bankası 1986 yılında tüm dünyada geçerli olan düzgünsüzlük ölçütü IRI'yı değerlendirme bileşeni olarak kabul etmiştir [7]. IRI değeri belirlenirken; bir motorlu taşıtın tek tekerleğinin yol yüzeyindeki tepkisi ile mekanik sistemin süspansiyon sapması hesaplanır. Simüle edilmiş süspansiyon hareketi biriktirilir ve kat edilen mesafeye bölünür, böylece IRI değeri elde edilir. Değerler genellikle $\mathrm{mm} / \mathrm{km}$ veya inç/mil birimleri ile ifade edilmektedir [8].

Yol yüzeyinin düzgünsüzlüğü; sürüş kalitesini ve araç işletme maliyetlerini olumsuz yönde etkilemektedir [9]. Üstyapının ilk yapıldığı durumu ile belli bir zaman kullanımından sonraki durum kalitesini kıyaslama işlemleri de Uluslararası Düzgünsüzlük İndeksi (IRI) ölçüm değerlerine göre Şekil 1'deki çizelgeden faydalanılmaktadır. Ölçülen IRI değerlerinde kaplama tabakası gerekli performans ölçütlerine sahip olmadığı takdirde, üstyapı yeni yapılmış ise, yükleniciye cezalı ödeme yapılmakta veya yükleniciden kaplamanın yeniden inşası istenmektedir $[7,10]$.

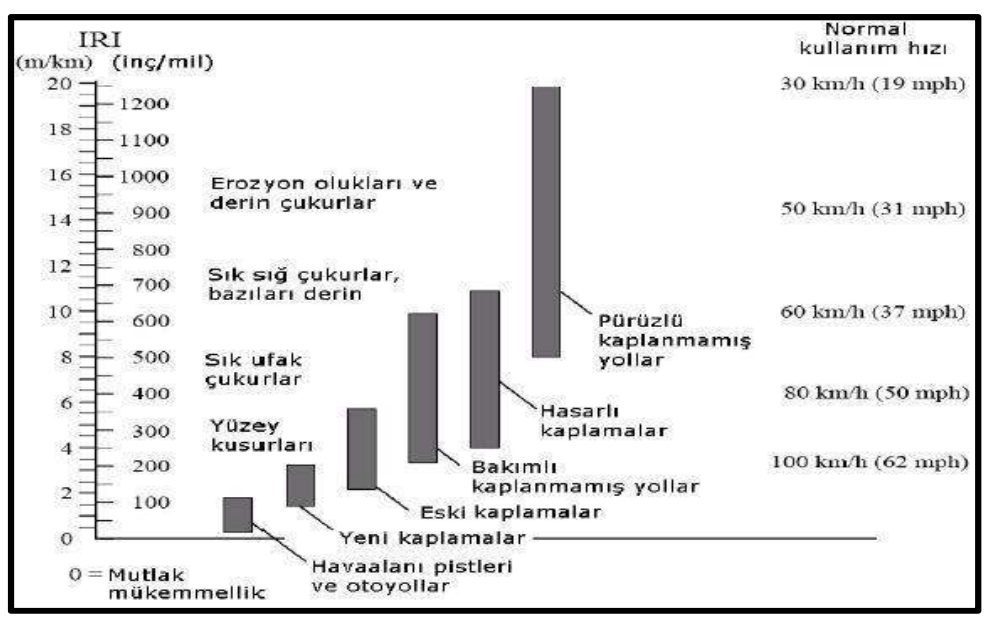

Şekil 1. IRI düzgünsüzlük indeksi şartname değerleri [7].

IRI değerleri Roughometer II ölçüm sonuçlarına göre 0 ile 11+ arasında değerler almaktadır. IRI değeri 0'a yaklaştıkça sürüş konforu açısından mükemmel bir yolu, 11+ değerlerinde ise görevini yerine getiremeyen çok kötü yol durumunu ifade etmektedir. Kaplaması yeni yapılmış 
yol kesimlerinde IRI değerinin 0-2 değerine sahip olması beklenmektedir. Düzgünsüzlük değerine göre kaplama kalitesinin değerlendirilmesi Tablo 1'de gösterilmektedir [11].

Tablo 1. IRI Değerlendirme Kriteri [11]

\begin{tabular}{|c|c|c|}
\hline IRI Değeri & IRI Sınıfi & Değerlendirme \\
\hline $0-2$ & Cok İyi & Yeni düzgün kaplama \\
\hline $3-4$ & İyi & İyi durumdaki kaplama; iyileştirmeye gerek yok \\
\hline $5-6$ & Orta & $\begin{array}{c}\text { Trafik hacmine bağlı olarak yakın gelecekte iyileştirmeye } \\
\text { ihtiyaç duyulabilir }\end{array}$ \\
& & Sürdürülebilir bir kullanım için iyileştirilmeli \\
\hline $7-10$ & Kötü & Hemen iyileştirme gerekir. \\
\hline $11+$ & Çok Kötü & \\
\hline
\end{tabular}

Literatürde IRI indeksini kullanarak yol yüzey düzgünsüzlüğünü ve etkilerini araştıran birçok çalışma vardır. Örneğin Abuluzi vd. [12] yaptıkları çalışmada uluslararası düzgünsüzlük indeksini (IRI) kullanarak Japonya'nın Hokkaido eyaletindeki kamuya açık yollarının yüzey kalitesini değerlendirmiştir. Bu amaçla farklı mevsimlerde IRI ölçümleri yapmış ve ölçüm sonuçlarını bir Coğrafi Bilgi Sistemi (CBS) yardımıyla Japonya Dijital Yol Haritası (DRM) veri tabanında işleyerek görselleştirmişlerdir. Çalışma sonucu elde edilen veriler ile yol sınıfı, şehir içi yol ağı ve farklı hava koşulları için yol yüzey düzgünsüzlüklerinin birbirlerinden farklı değerlendirilmesinin gerektiği ve bu amaçla bu durumları dikkate alan bir Üstyapı Yönetim Sisteminin oluşturulması gerektiğini önermişlerdir. Bir başka çalışmada Mubaraki [13], Suudi Arabistan'ın Jazan ve Cidde şehirleri arasındaki şehirlerarası yolda farklı yol yüzey kesitlerini inceleyerek IRI ile sırasıyla tekerlek izi, çatlama ve aşınma arasındaki ilişkiyi araştırmıştır. Yapılan analizlerden IRI-çatlama ve IRI-aşınma arasında \%95 güvenirlik düzeyinde anlamlı bir ilişki olduğu belirlenmiştir. IRI ile tekerlek izi arasında ise anlamlı bir ilişki olmadığ 1 görülmüştür. Çalışma sonucunda yol yüzeyindeki çatlama ve aşınmanın sürüş kalitesini aktif şekilde etkileyen problemler olduğu görülürken tekerlek izi ise bu yargının dışında kalmıştır.

Ihs [14], çalışmasında İsveç’te üstyapı düzgünsüzlüğünün trafik güvenliği üzerindeki etkisini incelemiştir. Yıl boyunca çeşitli trafik sınıfları için IRI $(\mathrm{mm} / \mathrm{m})$ ile kaza oranı (çarpışma/100 milyon aks $/ \mathrm{km}$ ) arasındaki ilişkiyi belirlemek için regresyon analizi yapılmıştır. Çalışma sonunda IRI değeri ne kadar yüksekse buna bağlı olarak kaza oranının da o kadar yüksek olduğu ortaya çıkmıştır. Yine benzer bir çalışmada trafik ve yol koşullarının kaza oranlarına etkisi incelenmiştir. Araştırma Doğu Endonezya'da kırsal şehirlerarası yollarda, 7 vilayette toplam 35 bölüm üzerinde gerçekleştirilmiştir. Kaza oranlarının modelini oluşturmak için 18 bölüm kullanılmıştır. Çalışmada model olarak Poisson dağılımı ile çok değişkenli regresyon lineer model seçilmiştir. Ölümcül kaza oranlarına; düzgünsüzlük endeksinin, yol genişliğinin, ortalama hızın ve motosikletli sürücü sayılarının önemli ölçüde katkıda bulunduğu görülmüştür. Çalışma sonuçlarına göre, motosikletlerin \%10 oranında artış göstermesi, ölüm oranını \%30 oranında artırmaktadır. Yol genişliğinin $0.5 \mathrm{~m}$ azalması ölüm oranının \%8.5 arttırırken, ortalama hızın $5 \mathrm{~km} / \mathrm{sa}$ artması ölüm oranının \%3.5 arttırmakta ve IRI endeksinin 1değer artırılması, ölüm oranını \%2.8 oranında artmasına sebep olmaktadır [15].

Cairney ve Bennett [16], çalışmalarını Avustralya / Victoria da $100 \mathrm{~km} / \mathrm{sa}$ hız sınırı olan iki yönlü bölünmemiş $1386 \mathrm{~km}$ uzunluğunda kırsal bir yolda gerçekleştirmiş̧lerdir. Araştırma kapsamında düzgünsüzlük ve çökme oluşumu arasında yüksek bir korelasyon olduğu görülmüştür. Kırbaş vd., [17], Türkiye'de BSK kaplamalı farklı on adet devlet yolundan alınan yüzey bozulmaları ile IRI arasındaki ilişkiyi incelemişlerdir. IRI ölçümünde Dynatest Mark-III 
Profilometre cihazı kullanılmıştır. Çalışma sonunda IRI üzerinde $\% 43.8$ yük kaynaklı, \%39 diğer sebepler ve \%17.2 iklim kaynaklı bozulmaların etkili olduğu sonucuna ulaşılmıştır.

Benzer bir çalışmada Al-Rousan vd., [18], ARRB Roughmeter III cihazını kullanarak Ürdün genelinde 9000 km'lik bir yol kesiminde inceleme yaparak bir yol yüzey düzgünsüzlük altyapısı hazırlamaya çalışmıştır. Elde edilen sonuçlardan, incelenen yol kesimlerinin yaklaşık olarak üçte birinin iyi, geri kalanın sürücülerin yüksek hızlarda araç kullanımı için risk teşkil ettiği sonucuna ulaşmışlardır.

Başka bir çalışmada, sinyalizasyonlu kavşaklarda düzgünsüzlük, makro pürüzlülük ve sürtünme dâhil üstyapı yüzey koşul parametrelerinin etkilerini ve katkılarını değerlendirmeye odaklanılmıştır. Analizler kapsamında sinyalize kavşak yaklaşımında bakım yapılmadan ve bakım yapıldıktan sonraki trafik durumu ve işleyişi değerlendirilmiş, analiz sonuçlarından yol yüzey problemleri bulunan kavşaklarda hava koşullarının (gece/gündüz ve güneşli-yağmurlu) sürücülerin hata yapması üzerinde önemli bir etkiye sahip olduğu belirlenmiştir. Yol yüzeyine bakım yapıldıktan sonra bu negatif etkinin daha da azaldığı ve düzelen düzgünsüzlükle, kazalarda önemli bir azalma meydana geldiği gözlemlenmiştir [19]. Kırbaş [4], çalışmasında sürüş konforunun üstyapıların hizmet seviyesinin yanında taşıt hızına da bağlı olup olmadığını araştırmıştır. Özellikle $60 \mathrm{~km} / \mathrm{sa}$ ve üzeri hızlarda, daha düşük hızlara nazaran sürüş konforu üzerinde, üstyapıların hizmet düzeyinin daha önemli bir değerlendirme parametresi olduğunu tespit etmiştir. Yani sürüş konforu değerlendirmesinde; yüksek hızlarda IRI değeri çok daha etkilidir. Fakat kavşak yaklaşımında sürücü davranışı ve bir başka deyişle hız değişiminin IRI ile etkileşimi üzerine detaylı bir çalışma yoktur. IRI'nın konfor yanında güvenlik üzerinde etkili olduğu da bilinmektedir. Kent içi ulaşımda kavşaklar güvenlik açısından en kritik noktalardır. Bu nedenle kavşak yaklaşımında yoldaki düzgünsüzlüğün de incelenmesine ihtiyaç vardır.

$\mathrm{Bu}$ çalışma kapsamında, şehir içi sinyalize kavşak yaklaşımlarındaki yol yüzey düzgünsüzlügünün şerit bazında araçların kavşak yaklaşımlarındaki hareketleri üzerindeki (yavaşlama, durma, şerit değiştirme) davranış etkisi araştırılmıştır.

\section{Materyal ve Metot}

Çalışmada ölçümler iki aşamada gerçekleştirilmiştir. İlk aşamada kavşak yaklaşımının hız değerleri mesafeye bağlı olarak üç kesit uzunlukta ayrı ayrı ölçülmüştür. Her şeritte mesafeye bağlı kesitlerdeki hız değerleri sürücü davranışı hakkında bilgi edinmemizi sağlamıştır. İkinci aşamada; üstyapı düzgünsüzlügü ölçümleri gerçekleştirilmiş, tüm şeritler için IRI değerleri elde edilmiştir.

Yapılan çalışma Isparta ili şehir içi hemzemin dört kollu, sinyal kontrollü Aypa Kavşağının üniversite-merkez gidiş doğrultusunda, tüm şeritleri (3 şerit; sağ-orta-sol) kapsayacak şekilde gerçekleştirilmiştir. İlk aşamada sürücü davranışının tespiti için kavşak başlangıcından 70 . metre ile 110. metre arasında (40 metre) birinci kesit hız ölçümü; 110. metre ile 150. metre (40 metre) arasında ikinci kesit hız ölçümü; 310. metre ile 345. metre arasında (35 metre) üçüncü kesit hız ölçümü alınmıştır. Sıfırıncı metre kavşak merkezi kabul edilmiştir. İkinci ve üçüncü kesit arasında kalan 160 metrelik kısımda hız ölçümü alınmamıştır. Çünkü bu kısımda yatay kurba mevcuttur. Amaç sürücü davranış hareketini incelerken yoldaki düzgünsüzlük etkisini araştırmaktır ve yatay kurba etkisini elimine etmek için bu kesimdeki mesafe ortalama hızı değerlendirilmemiştir. Yol boyunca hız ölçümü almak yerine belirli aralıklarla mesafe ortalama hız ölçümü kamera görüntülerinden çıkarılmaya çalışılmıştır. Üçüncü kesitte ise bir önceki kavşaktan çıkan araçların belli sabit hıza ulaştığı görülmüş ve bu kesimde mesafe ortalama 
hızında ivmelenme olmadığı kabul edilmiştir. Kesitlerde alınan hız ölçümleri sırasında araç cinsleri ve aynı aracın her kesitteki hız davranışları yavaşlatılmış video kamera çekimlerinden elde edilmiştir. Ölçümler 90 dakika boyunca, her şerit için, kesitlerde eş zamanlı olarak 3 adet video kamera ile alınmıştır. Bir buçuk saatlik ölçüm dört kat yavaşlatılmış görüntülerden ortalama 18x3 saatte değerlendirilmiş, mesafe bazında ortalama hız ölçümleri elde edilmiştir. Videoda sadece araçlar için geçiş veren, yeşil faz durumunda ve önde kuyruklanmanın olmadığ anlarda geçen araçlar dikkate alınacak şekilde elde edilmiştir. Amaç sürücü davranışını tespit etmek olduğundan aynı taşıtın, üç kesimdeki farklı kesit ortalama hız değerleri belirlenmiştir. Araştırma alanı Şekil 2'de gösterilmiştir.

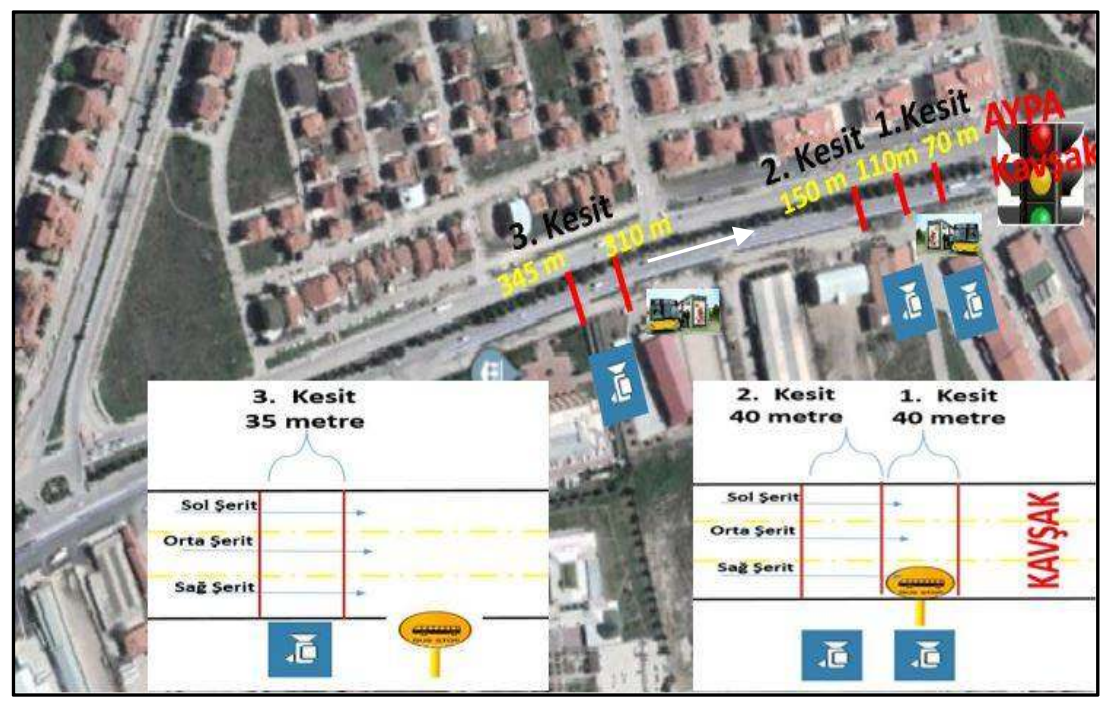

Şekil 2. Kavşak Ölçüm Plan Gösterimi

Her şerit için (sağ-orta-sol) video kameradan elli araç sayılarak 150 araç için hız verisi elde edilmiştir. Üç kesitte de hız davranışlarını görmek için rastgele seçilmiş araçların hız-mesafe grafikleri Şekil 3'te gösterilmiştir. Şekil 4'te de taşıt türüne göre otalama hız-mesafe grafikleri verilmiştir.
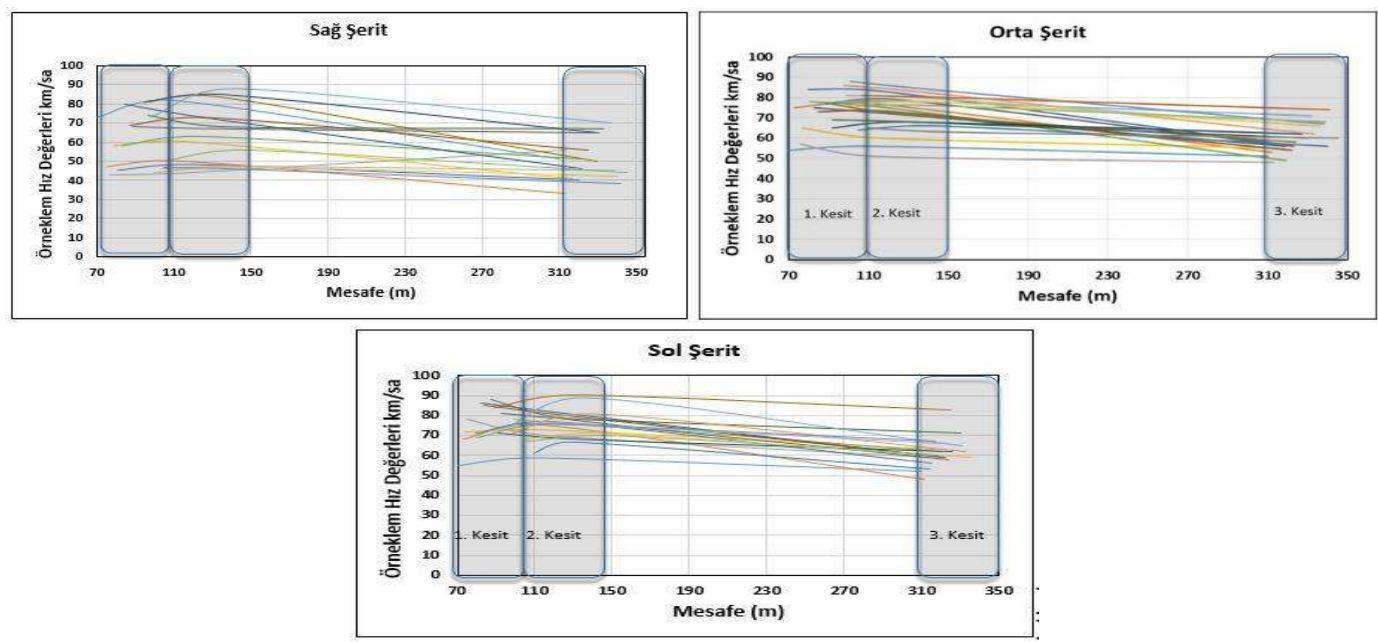

Şekil 3. Kesitlerdeki Örneklem Hız Değişimi 

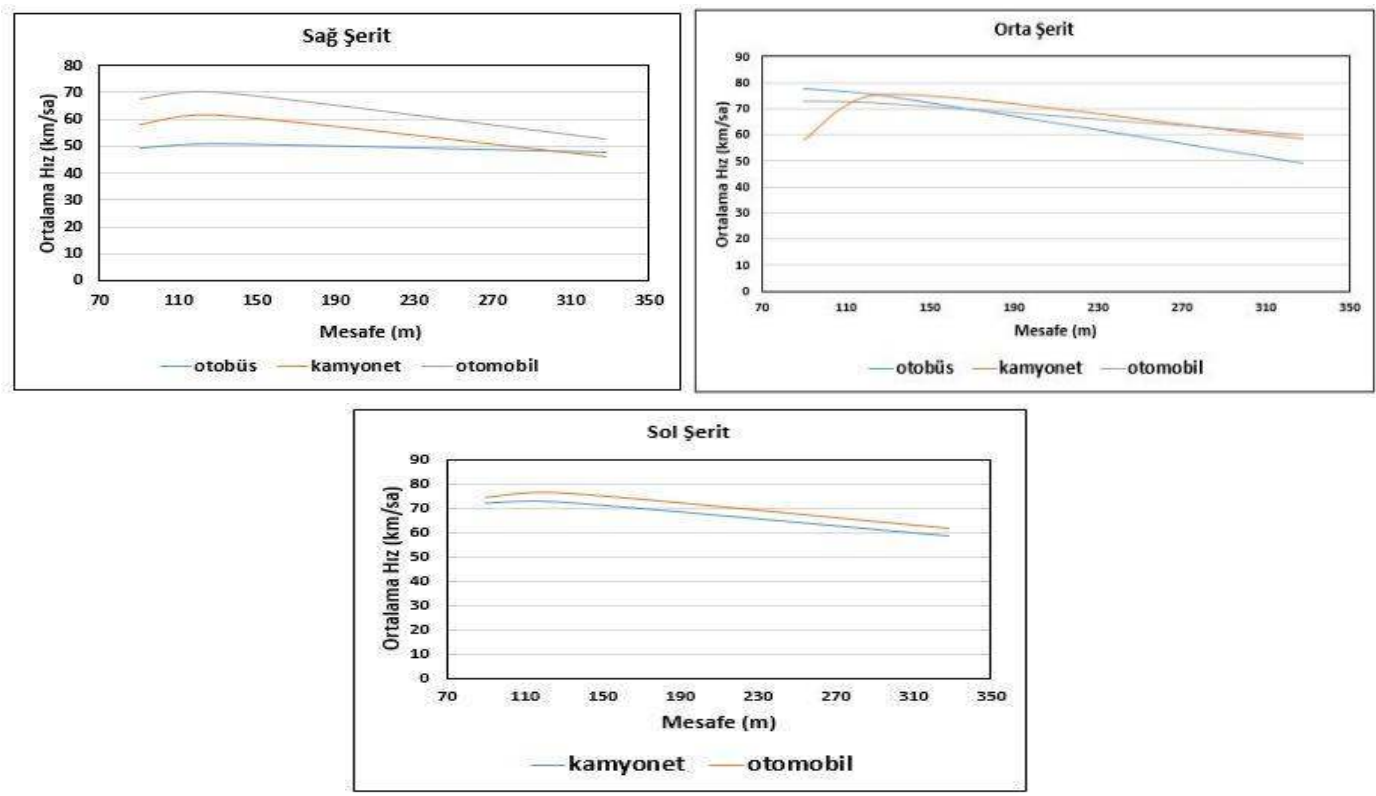

Şekil 4. Taşıt Türlerine Göre Hız Değişimleri

Şekil 4'te tüm şeritlerde üçüncü kesitten birinci kesite doğru (kavşak yaklaşımı) hızlarda bir artış görülmektedir. Sağ ve sol şeritlerde ise ikinci kesitten birinci kesite doğru hızlarda azalma tespit edilmektedir. Yapılan çalışmada, sadece yeşil faz zamanının göz önüne alınması, aynı araç için 3 farklı kesimde hız temin edilmesi ve gün içinde yoğun trafik koşullarında veri temin etmenin getirdiği zorluklar sonucunda, video kamera görüntülerinden elde edilen verilerle bile ihtiyaç olan ortalama hız-veri sayısına ulaşılamamıştır. Bu nedenle ölçülen verileri temsil edebilecek şekilde veri çoğaltılması gerçekleştirilmiştir. Bunun için yaygın olarak kullanılan ve trafikte hız davranışını temsil edebilecek veriler üzerinde daha önce farklı çalışmalarda da kullanılmış olan Monte Carlo yöntemi [20] tercih edilmiştir.

Çalışma kapsamında elde edilen mevcut hız verilerinden daha fazla veri üretmek için kullanılan Monte-Carlo yöntemini gerçek bir durumun stokastik modelini oluşturup, bu model üzerinden örnekleme deneyleri hazırlama tekniği olarak tanımlayabiliriz. Bir başka deyişle, incelen kesimde veri azlığı hassasiyetinin azlığına sebep olmakta ve gerçek dünyayı temsil etmesi mümkün olmaya bilmektedir. Davranışı analitik yöntemlerle değerlendirebilmek için analitik bir yaklaşım olan Monte Carlo Similasyon yöntemi gerçek veriyi taklit ederek yapay veri çoğaltma ile hız davranışını incelemeyi mümkün kılmaktadır [21,22,23]. Her bir şeritte elde edilen 50'şer veri, 1000 veri olacak şekilde üretilmiştir. Monte Carlo yöntemi veri azlığ1 durumunda modelin özelliklerini doğrulamak için uygulanmıştır. Geliştirilmiş olan bu hız modeli, hız dağılımını temsil edebilmiştir. Monte Carlo Yöntemi kullanılarak üretilen hız değerleri ile gerçek hız değerleri arasında ilişki her şerit ve her şeritteki kesimler için grafik ile gösterilmiştir (Şekil 5).

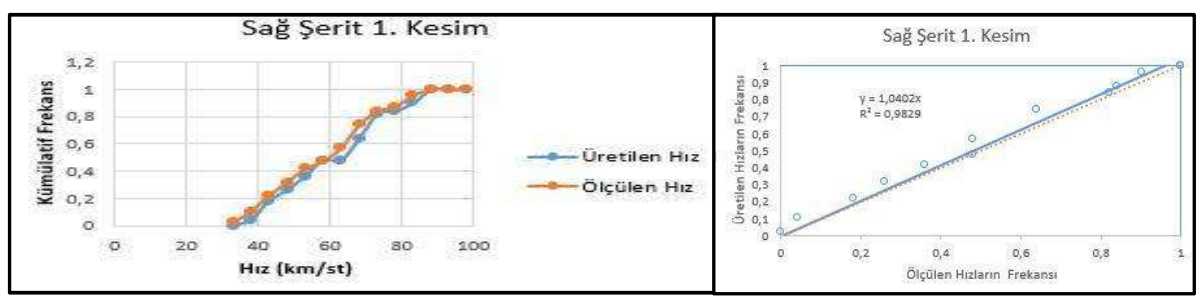

Şekil 5. Monte Carlo Yöntemi ile Üretilen Hız değerleri ile Ölçülen Hız Değerleri Arasındaki İlişki 


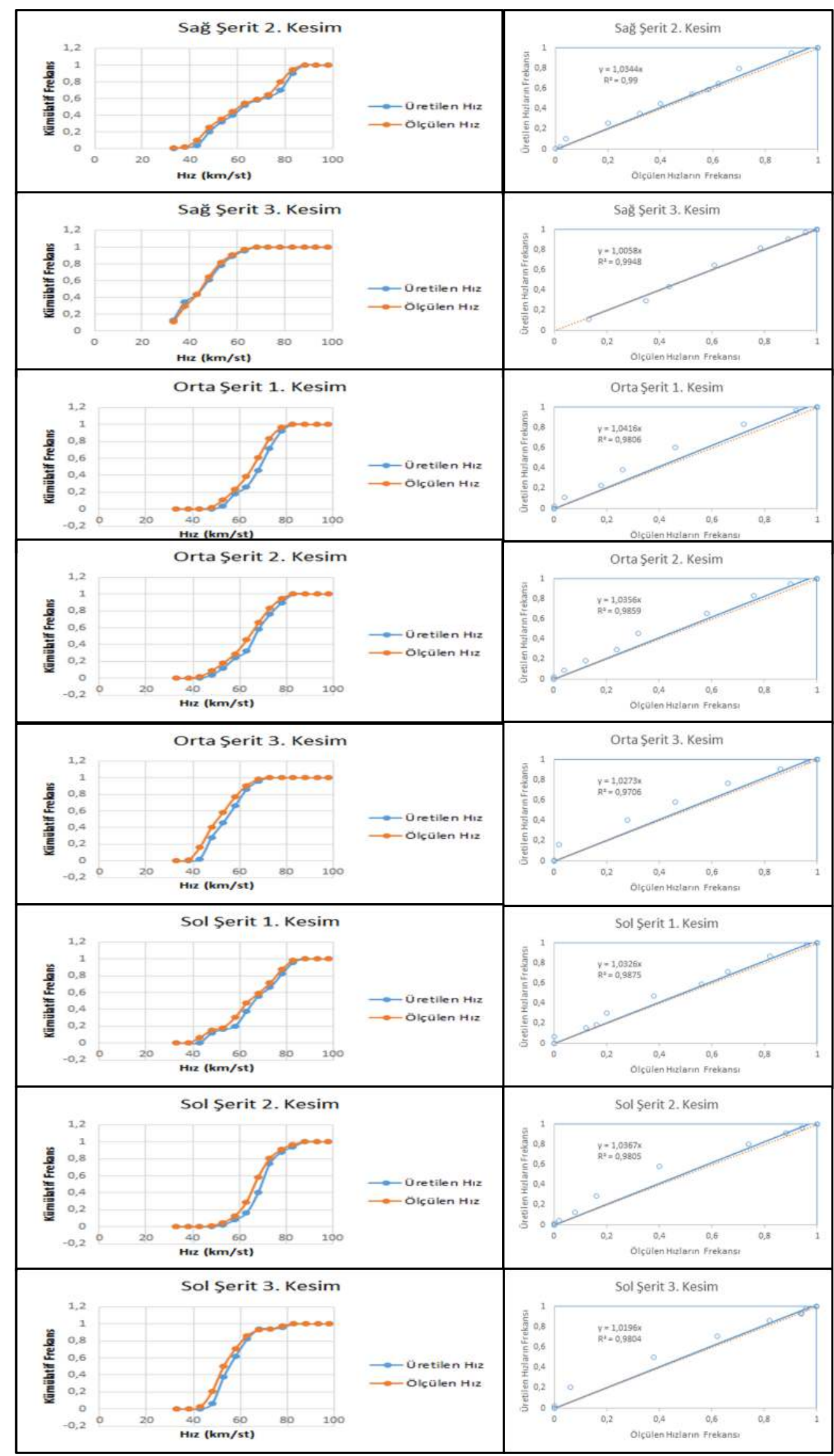

Şekil 5 (Devamı). Monte Carlo Yöntemi ile Üretilen Hız değerleri ile Ölçülen Hız Değerleri Arasındaki İlişki 
Monte Carlo Simülasyon Yöntemi mevcut üç şeritte, üç kesim için de ayrı ayrı uygulanmıştır. Ölçülen hız değerleri ile üretilen hız değerleri arasındaki ilişkiyi tespit edebilmek amacıyla aralarındaki korelasyon değerlerine bakılmıştır. Aralarında yüksek oranda (\%97-99) uygunluk gösteren ilişki çıkmıştır. Üretilen hız verileri ölçülen hız değerlerini çok iyi bir biçimde temsil edebilmektedir. Bir sonraki adımda, IRI değerleri ile karşılaştırılacak hız değerlerinde MonteCarlo ile üretilen hız değerleri kullanılmıştır.

Çalışmanın ikinci kısmında IRI ölçümü gerçekleştirilmiştir. IRI ölçümleri için ARRB Roughometer II cihazı kullanılmıştır. Cihazın hatasız ölçüm alabilmesi için ölçümler, sinyalizasyon devre sürelerinin flaşa geçtiği zaman dilimi olan, gece 03:00-05:00 saatleri arasında alınmıştır. Ölçüm aracının ani hızlanma ve yavaşlamalarından kaçınılması sağlanmış, taşıt ivmelenmesinin IRI üzerine olan etkisi elimine edilmiştir. Bunun için ölçüm esnasında araç hız sabitleyicisi kullanılmış, $50 \mathrm{~km} / \mathrm{sa}$ ile sürüş gerçekleştirilmiştir. Tablo 2.'de her şeritte üç kesit içinde hız ve IRI değerleri gösterilmiştir. Kavşak başlangıcından üçüncü kesitin sonuna kadar ki kısımda (350 metre) ölçülen IRI değerleri üç şerit içinde değişimleri Tablo 2'de gösterilmiştir.

Daha önce de bahsedildiği gibi, çalışmada sinyalizasyonun yeşil faz durumunda geçen taşıt hızlarının göz önünde bulundurulma sebebi IRI'nın sürücü davranışına olan etkisi incelenmektir. Sağ şerit boyunca araçlar 3. kesitten (310-350 metre) belirli bir sabit hız ile sinyalizasyona yaklaşmaktadırlar. Yeşil sinyali gören sürücü, bir sonraki sinyalizasyonu beklememek adına ne kadar kavşak yaklaşımında olsa da pozitif ivmelenme davranışı göstermektedir.

Tablo 2. Ölçülen Hız IRI Değer Aralıkları

\begin{tabular}{|c|c|c|c|}
\hline \multicolumn{4}{|c|}{ AYPA KAVŞAĞI } \\
\hline \multirow{4}{*}{ SAĞ ŞERITT } & & $\begin{array}{c}\text { Ölçülen Hız } \\
\text { Aralığı } \\
\end{array}$ & $\begin{array}{c}\text { Ölcçülen IRI } \\
\text { Değer Aralığı }\end{array}$ \\
\hline & Birinci Kesit & $43-81 \mathrm{~km} / \mathrm{sa}$ & $1,7-3,5$ \\
\hline & İkinci Kesit & $44-88 \mathrm{~km} / \mathrm{sa}$ & $1,4-2,5$ \\
\hline & Üçüncü Kesit & $33-70 \mathrm{~km} / \mathrm{sa}$ & $2,6-3$ \\
\hline \multirow{3}{*}{$\begin{array}{l}\text { ORTA } \\
\text { ŞERITT }\end{array}$} & Birinci Kesit & $54-88 \mathrm{~km} / \mathrm{sa}$ & $1,3-2,5$ \\
\hline & İkinci Kesit & $51-84 \mathrm{~km} / \mathrm{sa}$ & $1,6-3,3$ \\
\hline & Üçüncü Kesit & $48-74 \mathrm{~km} / \mathrm{sa}$ & $2,5-4,9$ \\
\hline \multirow{3}{*}{ SOL ŞERIT } & Birinci Kesit & $55-88 \mathrm{~km} / \mathrm{sa}$ & $1,7-3,8$ \\
\hline & İkinci Kesit & $59-90 \mathrm{~km} / \mathrm{sa}$ & $1,7-2,4$ \\
\hline & Üçüncü Kesit & $48-83 \mathrm{~km} / \mathrm{sa}$ & $2-5$ \\
\hline
\end{tabular}

Şekil 6'da kavşak yaklaşımından incelenen link boyunca (350 metre) her 10 metrede bir alınan IRI değerleri sağ-orta-sol şerit için grafikte gösterilmiştir.

Sağ şerit ikinci kesitte IRI değeri (1,7-3,5) birinci kesite göre daha düşük $(1,4-2,5)$ bir değere sahipken, hız değeri daha yükselmektedir. Yol düzgünsüzlüğü artıkça sürücü konfor ve güvenlik için negatif ivmelenme yapmaktadır. Sürücü sinyalizasyona doğru yakınlaştıkça beklemeden kavşağı terk etme davranışı sergilemek için pozitif ivmelenme hareketi göstermesi gerekirken, negatif ivmelenme göstermiştir. Bunun sebebi kavşak yaklaşımında IRI değerinin daha kötü bir değere sahip olmasından kaynaklandığı düşünülebilir. 


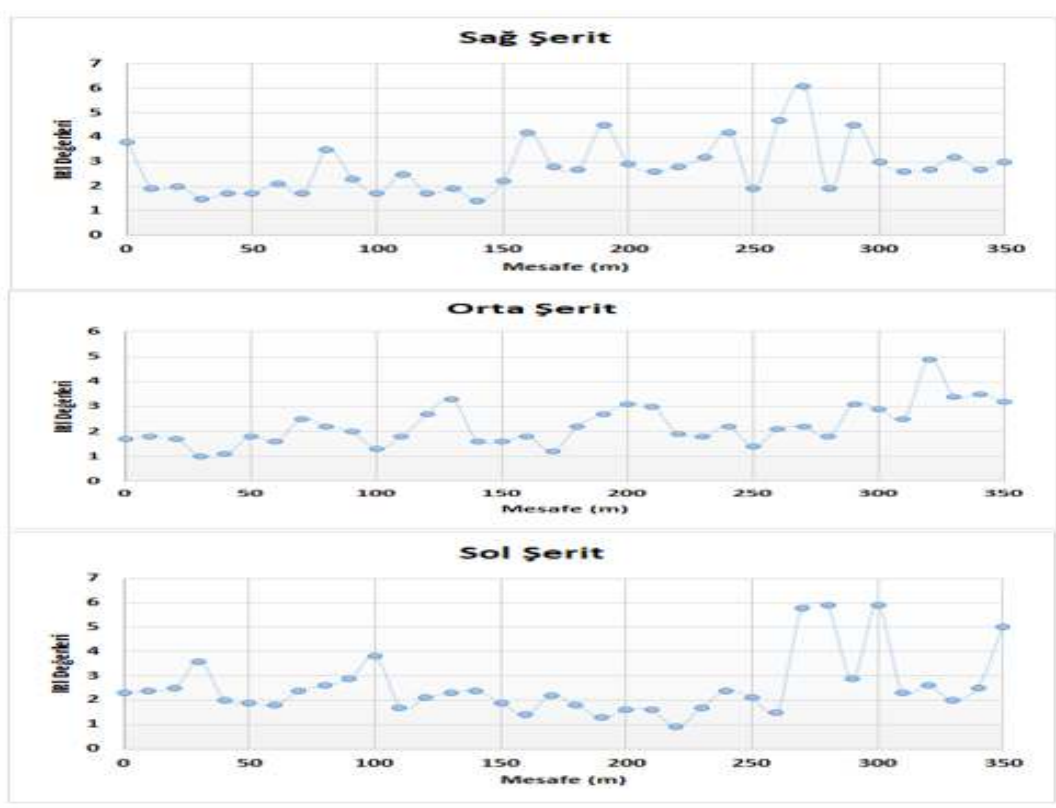

Şekil 6. Şerit Bazında IRI Değerleri

IRI ölçümü alınan sağ şeridin ilk kesiminde (70m-110m) ve $150 \mathrm{~m}-250 \mathrm{~m}$ arasında IRI değerlerinde normal olmayan bir yükseliş gözlenmektedir. Bunun sebebi bu kesimlerde otobüs duraklarının yer almasıdır. Durak etkisi ile dur kalkların ve ivmelenme değişkenliğinin sık yaşanması yüzünden IRI değeri bu kesitlerde tablo 1'de gösterilen orta ve kötü IRI sınıfı değerlerinde çıkmıştır. Sol şeritte aynı şekilde sağ şeritteki gibi bir durum söz konusudur. Kavşak yaklaşımında IRI değerinin artması ile birlikte hızlarda bir azalma olmuştur. Fakat kavşak yaklaşımında sağa ve sola dönüşlerde hız değişimi ile IRI arasında ilişki kurmak çok sağlıklı olmayabilir. En azından hızlarda yaşanan düşüşü direk IRI'ya bağlamak doğru olmayacaktır. $\mathrm{Bu}$ noktada orta şeritteki sürücülerin davranışı yorum yapabilmede daha fazla kolaylık sağlamaktadır. Orta şeritte sürücüye dışarıdan (dönüşler, otobüs durağı gibi) herhangi bir etki olmamaktadır. Orta şeritte; ikinci kesitteki IRI değeri $(1,6-3,3)$ birinci kesite $(1,3-2,5)$ göre daha yüksek, hız ise daha düşüktür. Yani hız ve IRI arasında negatif yönde bir ilişki mevcuttur. Bu da IRI değerinin yüksek olmasının sürücülerde ani negatif ivmelenmelere sebep olabileceğinin bir göstergesi olduğu söylenebilir.

\section{Sonuç ve Tartışma}

Yapılan çalışmada hemzemin sinyalizasyonlu şehiriçi kavşak yaklaşımında IRI'nın sürücü davranışı üzerindeki etkisi incelenmiştir. Bu amaçla üç şerit içinde üç kesitte aynı sürücüye ait araç hız değişimleri tespit edilmiştir. Bu tespit için ikinci bölümde detaylı olarak anlatıldığı gibi, üç adet video kamera aynı anda çekim yapmış, daha sonra çekimler yavaşlatılarak aynı araçların her bir görüntü ekranından geçiş sürelerinin tespiti gerçekleştirilmiştir. Veriler hassas bir şekilde elde edilmesi ihtiyacı nedeniyle veri sayısı yeterli görülmemiştir. Veri temin etmesi zor ve meşakkatli durumlarda az veriyle çalışmak çok hassas olmamaktadır. Bu nedenle ve sadece yeşil faz zamanı göz önüne alınması yüzünden, 3 farklı kesimde hız temin edilmesi Monte Carlo Simulasyon yöntemi ile gerçekleştirilmiştir. Daha sonra IRI değerleri ölçülmüştür. Hız ve IRI değerleri ile aralarında oluşan ilişki sonuçları tablo ve grafikler yardımıyla sunulmuştur. Sonuçlara göre; sağ ve sol şeritlerde kavşağa doğru (birinci kesit) IRI değerleri artış göstermektedir bununla birlikte, hızlarda azalış söz konusu olmaktadır. Kavşakta sağa ve sola dönüşlerin meydana gelmesi hızların bağımsız olarak sadece IRI'ya göre yorum yapmamızı engellemektedir. Orta şeritte ise kesintisiz ilerleme söz konusu olduğu için IRI ve 
sürücü hızları arasında daha doğru yorum yapabilmemizi sağlamıştır. Orta şeritte; IRI değeri kavşak merkezine doğru azalırken, hız değerinde artış görülmektedir. Yani IRI ile hız arasında negatif yönde bir ilişki mevcuttur. Gelecek çalışmalarda yoldaki makro ve mikro pürüzlülük etkisi de incelenmeli ve kavşak yaklaşımında özellikle orta şeritteki sürücü davranışı için yol üstyapı etkisi incelemeleri gerçekleştirilmelidir.

\section{Kaynaklar}

[1] Sayers M.W. and S. Karamihas. Interpretation of Road Roughness Profile Data. Final Report prepared for Federal Highway Administration,UMTRI 1996, 96-19.

[2] Wang, F., Easa, S. Analytical Evaluation of Ride Comfort on Asphalt Concrete Pavements. Journal of Testing and Evaluation, 2016, 44, 1671-1682.

[3] Hudson, W.R. Generalised Roughness Index. Paper Presented to the Annual Meeting. Transportation Research Board, Washington, DC, January 1978.

[4] Kırbaş, U. Konforlu Sürüş için Uluslararası Düzgünsüzlük İndeksi Sınır Değerlerinin Belirlenmesi, Journal of Engineering Sciences and Design, 2018, 6(2), 301-309.

[5] TERZİ,S., 2013, Modeling for pavement roughness using the ANFIS approach, Advances in Engineering Software 57 (2013) 59-64

[6] Haas, R., Hudson, W. R., Zaniewski, J. P. Modern Pavement Management, Malabar, Florida, Usa, Krieger Pub. Co, 1994.

[7] Sayers, M. W., Gilespie, T.D., and Queiroz, C.A.V. The International Road Roughness Experiment,Establıshıng Correlation and Calibration Standart for Measurements, 1986, Technical Paper 45, World Bank, Washington, D.C.

[8] National Cooperative Highway Research Program (NCHRP). Calibration of Response- Type Road Roughness Measuring Systems. NCHRP Report 228, 1978, Transportation Research Board, Washington, D.C., U.S.A.

[9] Flintsch, G.W., Valeri, S.M., Katicha, S.W., et al. Probe Vehicles Used to Measure Road Ride Quality: Pilot Demonstration. Transportation Research Record, 2012 (23), 158-165.

[10] KGM. Üstyapı Yönetim Sistemi Seminer Dokümanları, Karayolları Genel Müdürlügü, Teknik Araştırma Dairesi Başkanlığı, Üstyapı Şubesi Müdürlüğü, Ankara, 2006.

[11] User Manual Roughometer II. ARRB Group Ltd. 2 February 2007.

[12] Abulizi, N., Kawamura, A., Tomiyama, K., Fujita, S. Measuring And Evaluating Of Road Roughness Conditions With A Compact Road Profiler And ArcGIS. Journal of Traffic and Transportation Engineering 2016;3(5):3 9 8-411.

[13] Mubaraki, M. Highway Subsurface Assessment Using Pavement Surface Distress And Roughness Data. International Journal of Pavement Research and Technology 9 (2016) 393-402.

[14] Ihs, A. The Influence of Road Surface Condition on Traffic Safety and Ride Comfort. 6th International Conference on Managing Pavements: the Lessons, the Challenges, the Way Ahead, 19-24 October 2004, Brisbane Queensland, Australia.

[15] Tjahjono, T. The Effect of Traffic and Road Conditions to the Fatality Rates on Rural Roads in Eastern Indonesia. Proceedings of the Eastern Asia Society for Transportation Studies, Vol. 7, 2009. 
[16] Cairney, P. and Bennett, P. Relationship Between Road Surface Characteristics and Crashes on Victorian Rural Roads. ARRB Conference, 23rd, 30 July-1 August 2008, Adelaide, South Australia.

[17] Kırbaş, U., Karaşahin, M., Demir, B., Komut, M., Ünal, E.N. Bitümlü Sıcak Karışım Üstyapılarda Görülen Yüzey Bozulmaları ile Düzgünsüzlük Arasındaki İlişkilerin Modellenmesinde Bazı Yaklaşımlar, Journal of Engineering Sciences and Design, 2018.

[18] Al-Rousan, T., Asi, I., \& Baker, A. A. Roughness evaluation of Jordan highway network. In 24th ARRB Conference, Melbourne, Australia, 2010 October, (Vol. 41).

[19] Hussein, N., Hassan, R. Surface Condition and Safety at Signalised Intersections. International Journal of Pavement Engineering, 2017, 18(11), 1016-1026.

[20] Iryo-Asano, M., Alhajyaseen, W. K., \& Nakamura, H. Analysis and Modeling of Pedestrian Crossing Behavior During the Pedestrian Flashing Green Interval. IEEE Transactions on Intelligent Transportation Systems, 2015, 16(2), 958-969.

[21] Öztürk, L.İktisadi, İ. Ü., \& Bölümü-Malatya, E. Monte-Carlo Simulasyon Metodu ve Bir İşletme Uygulamas1, Doğu Anadolu Bölgesi Araştırma Raporu, 2004.

[22] Davies, R., Coole, T., \& Osipyw, D. The Application of Time Series Modelling and Monte Carlo Simulation: Forecasting Volatile Inventory Requirements. Applied Mathematics, 2014, 5(8), 1152-1168.

[23] Robinson, S. Simulation: The Practice of Model Development and Use. John Wiley and Sons, Chichester, 2004.

[24] Shahin, M., Y. Pavement Management for Airports, Roads, Parking Lots, Kluwer Academic Publishers, Boston, London, U.K, 2002. 